\title{
THE MATERNAL, SANITATION, CHILD'S INFECTIOUS DISEASE HISTORY AND DIARRHEA AMONG UNDER 5 AGE CHILDREN INSAMPANG
}

\author{
Ernia Haris Himawati ${ }^{\mathbf{a}^{*}}$; Laila Fitria ${ }^{\mathrm{b}}$ \\ ${ }^{a b}$ University of Indonesia ; Margonda Raya Street ; Depok 16424 ; Indonesia
}

\begin{abstract}
Diarrhea is the second leading cause of children death in the world after pneumonia. The case managements have been increased and developed but the mortality rate due to diarrhea is still high. Sub-Saharan Africa and Southeast Asia were known as the highest case regions of diarrhea, including Indonesia as part of the developing countries. The purpose of this study was to analyze the relationship between maternal factors, sanitation, and a history of childhood infectious diseases with the incidence of diarrhea in Sampang. The research used a cross-sectional design study with a total sampling technique. The source data was from Riskesdas 2018 by Indonesian Health Ministry and analyzed by univariate, bivariate, and multivariate. The result of multivariable logistic regression analysis showed that maternal factors: hand washing behavior (OR 4.687; 95\% CI 0.473-46.469); education level (OR 1.815; 95\% CI 0.108-1177), waste management (OR 4.333; 95\% CI 0.509-36.011) and a history of infectious disease in children (OR 5.421; $95 \%$ CI $1.444-20.354)$.
\end{abstract}

Keywords: mother; children; sanitation; diarrhea

\section{Introduction}

There were about 5 million deaths in children around the world and a half of it was caused by diarrhea (Liu et al., 2016). The highest mortality case of diarrhea is in Sub-Saharan Africa and South Asia and several developing countries where expressed the number of deaths per year typically range from $50-150$ per 100.000 (Bernadeta, Hannah, \& Roser, 2019). As a part of developing country, the prevalence of diarrhea in Indonesia is still high at $6.7 \%$ in children under 5 years with the highest prevalence in Aceh and several regions in Java. It was reported that in East Java, the prevalence of cases was $6.6 \%$, almost reaching the national prevalence of diarrhea cases in the country. The mortality rate of diarrhea in children is mainly caused by dehydration, for example hypovolemia, electrolyte imbalance and acidosis. The incidence of diarrhea is commonly found in developing countries (UNICEF, 2016).

\footnotetext{
${ }^{*}$ ) Corresponding Author (Ernia Haris Himawati)

E-mail: erniaharishimawati@gmail.com
}

The cause of diarrhea is often associated with infectious diseases, especially in the digestive tract, by microbes and parasites. Infection is spread through fecal-oral transmission both direct and indirect contact with infected people such as contaminated water and food (Radlović, Leković, Vuletić, Radlović, \& Simić, 2015). Diarrhea is defined as excretion of watery stools with a liquid and formless consistency. There are two types of diarrhea, namely infectious diarrhea and noninfectious diarrhea. Diarrhea due to infection (infectious diarrhea) is usually caused by virus, parasite or bacteria. They spread very quickly through person to person, especially daycare. While noninfectious diarrhea is usually caused by toxins or toxic substances in patients with cystic fibrosis (Krause, 2018).

Some pathogens were found as causes in developing countries related to diarrhea diseases such as rotavirus as the most common cause, enteropathogenic bacteria such as Shigella, Salmonella non-typical, ampylobacter, 
Yersinia and others are common causes of foodborne foods. These transmissions occur because they can produce emetics and or enterotoxins (Kotloff, 2017). It is known that rotavirus is the most common cause of the incidence of diarrhea as an estimated 128,500 deaths among children under 5 years in the world (Troeger et al., 2018).

The common sign and symptom of diarrhea are fever, nausea, vomiting and watery stool more than 4 times a day with the cause of it is rotavirus in the most of children under 2 years old (Imanadhia, Ranuh, \& Nuswantoro, 2019). The use of rotavirus vaccine has been extended and already contributed to reduce the burden but there still higher risk of diarrhea cases in children under 5 such as a low access to the good water and sanitation which commonly found in developing countries (Troeger et al., 2018).

A study in Pekanbaru reported that several factors were associated with diarrhea in children, including hand washing behavior and education level which resulted in a value of $p<0.05$ (Hartati \& Nurazila, 2018). Other research also showed that household sanitation influenced the incidence of diarrhea in Kupang with an OR value of 4,527, means that poor household sanitation was more at risk of experiencing diarrhea incidence in children by 4.5 times compared to good household sanitation (Irfan, 2016).

\section{Method}

This research used a cross-sectional study design (snapshot method) and total sampling technique. The source of data was from a national scale study by the Ministry of Health of the Republic of Indonesia, Riskesdas 2018. The number of samples obtained 207 under 5 age children. As many as $8.2 \%$ of incident cases in Sampang, higher than the prevalence of the province of $6.7 \%$ (Kementrian Kesehatan RI, 2018). The independent variable divided into three characteristics: maternal, household sanitation and children's infectious disease history, in this case was Acute Respiratory Infection (ARI). The maternal characteristics including hand washing behavior and education level, sanitation characteristics include drinking water sources, waste disposal and waste management and toilet usage, while the health status of children includes complete immunization and a history of infectious diseases.
Statistical tests were perfomed using certain software to analyze the variables in univariate, bivariate and multivariate level. Bivariate analysis used a chi-square test while multivariate analysis used a multivariable logistic regression test (Hastono, 2016).

\section{Result and Discussion}

Table 1. The Univariate Analysis of The Factors Related to Diarrhea

\begin{tabular}{|c|c|c|}
\hline Characteristic & $\begin{array}{c}\text { Frequency } \\
(\mathrm{n})\end{array}$ & $\begin{array}{c}\text { Percent } \\
(\%)\end{array}$ \\
\hline \multicolumn{3}{|l|}{ Maternal } \\
\hline Low education level & 83 & 40.1 \\
\hline $\begin{array}{l}\text { High education } \\
\text { level }\end{array}$ & 124 & 59.9 \\
\hline $\begin{array}{l}\text { Lack of hand } \\
\text { washing behavior }\end{array}$ & 25 & 12.1 \\
\hline $\begin{array}{l}\text { Good hand washing } \\
\text { behavior }\end{array}$ & 181 & 87.9 \\
\hline \multicolumn{3}{|l|}{ Sanitation } \\
\hline No latrine & 18 & 8.7 \\
\hline Latrine & 189 & 91.3 \\
\hline $\begin{array}{l}\text { Unprotected } \\
\text { drinking } \quad \text { water } \\
\text { source }\end{array}$ & 136 & 65.7 \\
\hline $\begin{array}{l}\text { Protected drinking } \\
\text { water source }\end{array}$ & 71 & 34.3 \\
\hline No sewage system & 171 & 82.6 \\
\hline Sewage system & 36 & 17.4 \\
\hline $\begin{array}{ll}\text { Bad } & \text { waste } \\
\text { management } & \end{array}$ & 158 & 76.3 \\
\hline $\begin{array}{ll}\text { Good } & \text { waste } \\
\text { management } & \\
\end{array}$ & 49 & 23.7 \\
\hline \multicolumn{3}{|l|}{ Child } \\
\hline $\begin{array}{l}\text { Infection } \quad \text { history } \\
\text { (ARI) }\end{array}$ & 19 & 9.2 \\
\hline $\begin{array}{l}\text { No infection history } \\
\text { (ARI) }\end{array}$ & 188 & 90.8 \\
\hline $\begin{array}{l}\text { Incomplete } \\
\text { immunization }\end{array}$ & 80 & 38.6 \\
\hline $\begin{array}{l}\text { Complete } \\
\text { immunization }\end{array}$ & 127 & 61.4 \\
\hline
\end{tabular}

As performed in table 1, the maternal factor; education level was divided into two namely low and high. The proportion of mothers with low education level is $40.1 \%$ and mothers with high education level are $59.9 \%$. While mothers with a good hand washing habits amounted to $87.9 \%$, and lack of hand washing behavior was $12.1 \%$. In the sanitation variable, houses that do not use latrines are as much as $8.7 \%$, those that use latrines as much as $91.3 \%$, unprotected drinking water sources as much as $65.7 \%$, 
protected drinking water sources as much as $34.3 \%$, houses without sewage system as much as $82.6 \%$, houses with sewage as much as $17.4 \%$, $76.3 \%$ of poorly managed waste and properly managed waste were only $23.7 \%$. in the child variable, the history of infection was diagnosed by doctors was $9.2 \%$, children without a history of infection (ARI) were 90.8\%, while children with complete immunization status were $61.4 \%$ and incomplete immunization status was $38.6 \%$.

The maternal factor plays an important role due to the knowledge of them integrated with the management of childhood diseases especially in diarrhea cases. Overall current study showed that mother with a good health knowledge regarding hygiene, clean water, dietary and or feeding management were done to reduce the burden of diarrhea among children (Abbas, Chandra Pandey, Verma, \& Kumar, 2018). The lack of adequate water, hygiene and sanitation promote transmission of person-to-person spread by the fecal-oral route. The role of immune ability of the body does impact the infection mechanism in children as a host (Kotloff, 2017). The infection mechanism affects the small and or the large bowel causing invasion and destruction of the mature epithelial tissue, depend on the type and pathogenic effect in both parts (Radlović et al., 2015).

After the bivariate analysis test (table 2), household with sewage system had a value of $p$ $<0.05$ with an OR of 0.344 . The percentage of households that did not use sewage and diarrhea was $6.4 \%$, households that used sewage system and had children with diarrhea were $16.7 \%$. The household waste management factor has a value of $p>0.05$ with OR 5.408. Households that have poor waste management and have diarrhea under fives of $10.1 \%$, while households that have good waste management and have children with diarrhea of $2 \%$. In children with a history of infectious disease (ARI), a p value $<0.05$ with OR 5.238. Children with a history of infectious diseases and having diarrhea by $26.3 \%$ while children who have no history of infection with diarrhea by $6.4 \%$.

Table 3 showed the final result of multivariate selection using regression logistic analysis. Based on the test result, it was found that the characteristics of maternal with hand washing behavior variables had an OR value of 4,687 . The outcome showed that children at risk of diarrhea by 4.6 times in women who are not accustomed to doing hand washing compared to women who had a good hand washing behavior. The result of this study was in line with the results of previous studies conducted by Rifai, et al. which showed that children with mothers who are not accustomed to hand washing behavior were at 6.6 times the risk of having diarrhea (Rifai, Wahab, \& Prabandari, 2016). Lack of hand washing habit is highly related to the incidence of infections that occur in humans, especially in children. Unclean hands become a medium of transmission of germs and cause disease. It will further increase the risk of diarrhea and other infectious diseases which impact on the absorption of nutrients (UNICEF, 2014).

Table 2. Bivariate Analysis of Factors Related to Diarrhea

\begin{tabular}{|c|c|c|c|c|c|}
\hline \multirow[t]{2}{*}{ Characteristic } & \multicolumn{2}{|c|}{$\begin{array}{l}\text { Diarrhea } \\
(\%)\end{array}$} & \multirow[t]{2}{*}{ OR } & \multirow[t]{2}{*}{$\begin{array}{c}\mathrm{P} \text { - } \\
\text { value }\end{array}$} & \multirow[t]{2}{*}{$\begin{array}{c}\text { 95\%CI } \\
\text { Lower- } \\
\text { Upper }\end{array}$} \\
\hline & Yes & No & & & \\
\hline \multicolumn{6}{|l|}{ Maternal } \\
\hline $\begin{array}{l}\text { Low education } \\
\text { level }\end{array}$ & 9.6 & 90.4 & 1.363 & 0.541 & $\begin{array}{l}0.504- \\
3.689\end{array}$ \\
\hline $\begin{array}{l}\text { Lack of hand } \\
\text { washing } \\
\text { behavior }\end{array}$ & 8.8 & 91.2 & 2.327 & 0.7 & $\begin{array}{l}0.295- \\
18.354\end{array}$ \\
\hline $\begin{array}{l}\text { Good hand } \\
\text { washing } \\
\text { behavior }\end{array}$ & 4.0 & 96.0 & & & \\
\hline \multicolumn{6}{|l|}{ Sanitation } \\
\hline No latrine & 0.0 & 100 & 1.099 & 0.372 & $\begin{array}{l}1.051- \\
1.149\end{array}$ \\
\hline Latrine & 9.0 & 91.0 & & & \\
\hline $\begin{array}{l}\text { Unprotected } \\
\text { drinking } \\
\text { water source }\end{array}$ & 7.4 & 92.6 & 0.726 & 0.597 & $\begin{array}{l}0.264- \\
1.996\end{array}$ \\
\hline $\begin{array}{l}\text { Protected } \\
\text { drinking } \\
\text { water source }\end{array}$ & 9.9 & 90.1 & & & \\
\hline $\begin{array}{l}\text { No sewage } \\
\text { system }\end{array}$ & 6.4 & 93.6 & 0.344 & 0.042 & $\begin{array}{l}0.118- \\
1.001\end{array}$ \\
\hline $\begin{array}{l}\text { Sewage } \\
\text { system }\end{array}$ & 16.7 & 83.3 & & & \\
\hline $\begin{array}{l}\text { Bad waste } \\
\text { management }\end{array}$ & $\begin{array}{l}10.1 \\
89.9\end{array}$ & & 5.408 & 0.08 & $\begin{array}{l}0.699- \\
41.870\end{array}$ \\
\hline $\begin{array}{l}\text { Good waste } \\
\text { management }\end{array}$ & 2.0 & 98.0 & & & \\
\hline \multicolumn{6}{|l|}{ Child } \\
\hline $\begin{array}{l}\text { Infection } \\
\text { history (ARI) }\end{array}$ & 26.3 & 73.7 & 5.238 & 0.003 & $\begin{array}{l}1.615- \\
16.991\end{array}$ \\
\hline $\begin{array}{l}\text { No infection } \\
\text { history (ARI) }\end{array}$ & 6.4 & 93.6 & & & \\
\hline $\begin{array}{l}\text { Incomplete } \\
\text { immunization }\end{array}$ & 7.5 & 92.5 & 0.855 & 0.767 & $\begin{array}{l}0.303- \\
2.411\end{array}$ \\
\hline $\begin{array}{l}\text { Complete } \\
\text { immunization }\end{array}$ & 8.7 & 91.3 & & & \\
\hline
\end{tabular}

Mother's education level is also a risk factor for children to have diarrhea. In the result of the multivariate analysis, the OR was 1,815 
which showed that the mother's education level affected the increasing risk of diarrhea among children. A previous research conducted in Purworejo, mother's education level is one of the determinants of diarrhea cases in children (Alma, Widowati, \& Wibowo, 2017). That was because the higher the level of mother's education, the more awareness of hygiene and good sanitation behavior became (Melese, Paulos, Astawesegn, \& Gelgelu, 2019).

A previous research conducted by Syachrizal showed that household waste management statistically affected the incidence of diarrhea in infants in Aceh (Syachrizal, 2016). Another related research showed that there was a significant association between household waste and diarrhea among children in Juntinyuat, Indramayu (Akbar, 2018). A well waste management as part of good sanitation efforts will reduce the risk of diarrhea by $40 \%$ in the world (UNICEF, 2016).

Table 3. Multivariate Analysis of Factors Related to Diarrhea

\begin{tabular}{lccc}
\hline \multicolumn{1}{c}{ Characteristic } & OR & $\begin{array}{c}\text { P- } \\
\text { value }\end{array}$ & $\begin{array}{c}95 \% \mathrm{CI} \\
\text { Lower- } \\
\text { Upper }\end{array}$ \\
\hline $\begin{array}{l}\text { Maternal } \\
\text { hand washing } \\
\text { behavior }\end{array}$ & 4.687 & 0.187 & $0.473-46.469$ \\
$\begin{array}{l}\text { Education level } \\
\begin{array}{l}\text { Sanitation } \\
\text { Waste management }\end{array}\end{array}$ & 1.815 & 0.316 & $0.108-1.177$ \\
$\begin{array}{l}\text { Child } \\
\begin{array}{l}\text { Infectious disease } \\
\text { history (ARI) }\end{array}\end{array}$ & 5.421 & 0.012 & $1.444-20.354$ \\
\hline
\end{tabular}

In the history of infectious diseases, the $\mathrm{p}$ value is 0.05 with an OR of 5,421. in statistics, historical data infectious disease, in this case is a respiratory disease diagnosed by doctors in Sampang have statistically approved to the relationship with the incidence of diarrhea in children. Based on OR values, children with a history of ARI have a 5.4 times more risk of diarrhea compared with children without a history of ARI. Several studies linking respiratory system disease with the occurrence of diarrhea as one of the causes of diarrhea outside the oral pathway or referred to as parenteral diarrhea or infantile diarrhea which can increase mortality in children by $24-50 \%$. This also related to cleanliness and hand washing habits. Although it is still unclear the exact cause, but a study shows that in America, rotavirus can invade through the respiratory tract and cause infantile diarrhea and become a serious problem because most attacks children one year old (Bobak \& Guerrant, 2015).

\section{Conclusion and Suggestion}

Based on the statistical analysis results, several factors had related to the incidence of diarrhea among under 5 age children in Sampang. they were maternal factor of hand washing behavior and education level, sanitation factor of household waste management and children's infectious disease history. The research related to these contents need to be elaborated further.

\section{Acknowledgments}

Thank you to the several parties who have supported this research, including Dr. Laila Fitria, S.KM,M.KM as the supervisor, District Health Office of Sampang and the Health Research and Development Agency of Indonesian Ministry of Health.

\section{References}

Abbas, J., Chandra Pandey, D., Verma, A., \& Kumar, V. (2018). Management of acute diarrhea in children: is the treatment guidelines is really implemented? International Journal of Research in Medical Sciences, 6(2), 539. https:// doi.org/10.18203/23206012.ijrms20180294

Akbar, H. (2018). Determinan Epidemiologis Kejadian Diare Pada Anak Balita di Wilayah Kerja Puskesmas Juntinyuat. Jurnal Ilmiah Keperawatan Stikes Hang Tuah Surabaya, 13.

Alma, L. R., Widowati, T., \& Wibowo, T. A. (2017). Determinan sosial kejadian diare akut pada anak usia 0-59 bulan di Purworejo. Berita Kedokteran Masyarakat, 33(7), https://doi.org/10.22146/bkm.18150

Bernadeta, D., Hannah, R., \& Roser, M. (2019). Diarrheal Diseases. Our World in Data. Retrieved from https://ourworldindata.org/diarrhealdiseases

Hartati, S., \& Nurazila, N. (2018). Faktor Yang Mempengaruhi Kejadian Diare Pada Balita Di Wilayah Kerja Puskesmas Rejosari Pekanbaru. Jurnal Endurance, 3(2), 400. https:// doi.org/10.22216/jen.v3i2.2962

Hastono, S. P. (Universitas I. (2016). ANALISA DATA PADA BIDANG KESEHATAN. 
Depok: PT RAJAGRAFINDO PERSADA. Imanadhia, A., Ranuh, I. R. G., \& Nuswantoro, D. (2019). Etiology Based on Clinical Manifestation of Acute Diarrhea Incidence of Children Hospitalized in Dr. Soetomo General Hospital Surabaya Period 20112013. Biomolecular and Health Science Journal, 2(1), 31. https:/ / doi.org/10.20473/bhsj.v2i1.12744

Irfan. (2016). Risk Factors and Predictive Model of Diarrhea in Kupang. 12(1), 1-10.

Kementrian Kesehatan RI. (2018). Hasil Utama Riset Kesehatan Dasar Jawa Timur 2018. Jakarta: Badan Penelitian Dan Pengembangan Kesehatan, Kementrian Kesehatan Republik Indonesia, 1-82.

Kotloff, K. L. (2017). The Burden and Etiology of Diarrheal Illness in Developing Countries. Pediatric Clinics of North America, 64(4), 799-814.

https://doi.org/10.1016/j.pcl.2017.03.006

Krause, M. (2018). Infektiose Diarrhoe. Praxis, 85(40), 1249-1252.

Liu, L., Oza, S., Hogan, D., Chu, Y., Perin, J., Zhu, J., ... Black, R. E. (2016). Global, regional, and national causes of under- 5 mortality in 2000-15: an updated systematic analysis with implications for the Sustainable Development Goals. The Lancet, 388(10063), 3027-3035. https://doi.org/10.1016/S01406736(16)31593-8

Melese, B., Paulos, W., Astawesegn, F. H., \& Gelgelu, T. B. (2019). Prevalence of diarrheal diseases and associated factors among under-five children in Dale District, Sidama zone, Southern Ethiopia: A cross- sectional study. BMC Public Health, 19(1), 1-10. https://doi.org/10.1186/s12889-0197579-2

Radlović, N., Leković, Z., Vuletić, B., Radlović, V., \& Simić, D. (2015). Acute diarrhea in children. Srpski Arhiv Za Celokupno Lekarstvo, 143(11-12), 755-762. https://doi.org/10.2298/SARH1512755R

Rifai, R., Wahab, A., \& Prabandari, Y. S. (2016). Kebiasaan cuci tangan ibu dan kejadian diare anak: Studi di Kutai Kartanegara. Berita Kedokteran Masyarakat, 32(11), 409414.

Syachrizal. (2016). Hubungan penanganan sampah dengan kejadian diare di wilayah kerja Puskesmas Ingin Jaya Kabupaten Aceh Besar. J Kes Ilm Nasuwakes, 9(1), 6975.

Troeger, C., Khalil, I. A., Rao, P. C., Cao, S., Blacker, B. F., Ahmed, T., ... Reiner, R. C. (2018). Rotavirus Vaccination and the Global Burden of Rotavirus Diarrhea among Children Younger Than 5 Years. JAMA Pediatrics, 172(10), 958-965. https://doi.org/10.1001/jamapediatrics.20 18.1960

UNICEF. (2014). The Impact of Poor Sanitation on Nutrition. Sanitation and Hygiene Applied Research for Equity, 1-12.

UNICEF. (2016). One is too many One too many Ending is. Retrieved from https:/ / data.unicef.org/wpcontent/uploads/2016/11/UNICEFPneumonia-Diarrhoea-report2016-webversion_final.pdf 